\begin{tabular}{c} 
Volume and Issues Obtainable at Center for Sustainability Research and Consultancy \\
Journal of Accounting and Finance in Emerging Economies \\
ISSN: 2518-0318 ISSN (E) 2518-8488 \\
Volume 6: Issue 2 June 2020 \\
CSRᄃ \\
Journal homepage: $\underline{\text { ww.publishing.globalcsrc.org/jafee }}$ \\
\hline
\end{tabular}

\title{
Response of Manufacturing Sector to Financial Liberalization in Pakistan
}

\author{
${ }^{1}$ Saira Baloch, ${ }^{2}$ Kaneez Fatima, ${ }^{3}$ Jameel Ahmed, ${ }^{4}$ Amna Noor \\ ${ }^{1}$ Lecturer and M.Phil Scholar at Institute of Management Sciences (IMS), University of Balochistan, Pakistan \\ ${ }^{2}$ Assistant Professor, IMS, university of Balochistan, Quetta, Pakistan, fatima.sohail@ hotmail.com \\ ${ }^{3}$ Assistant Professor, IMS, University of Balochistan, Quetta, Pakistan, jamil_ims@yahoo.com \\ ${ }^{4}$ Assistant Professor, Department of management Sciences, "The Islamia University of Bahawalpur, Pakistan, \\ damnanoorch@gmail.com
}

\begin{tabular}{l} 
ARTICLE DETAILS \\
\hline History \\
Revised format: May 2020 \\
Available Online: June 2020 \\
\\
\hline Keywords \\
Corporate governance \\
compliance, global financial \\
crisis, stock liquidity, Pakistani \\
listed firms \\
\hline
\end{tabular}

JEL Classification

G01, G12, G34

\begin{abstract}
It has been believed that financial liberalization can stimulate industrial growth which may be translated into overall growth of the economy by efficient allocation of credit which generates investment opportunities by reducing the cost of investment, deregulations, privatizations and reduced capital controls. This paper aims to examine the impact of financial liberalization on industrial response in manufacturing industry measured as new firm entry. Moreover, moderating effect of external finance dependence on the relationship of financial liberalization and firm entry is estimated. We estimate the model using Generalized methods of moments and found that external finance dependence has a significant negative impact of new firm entry, while financial liberalization has a positive but insignificant impact on firm entry. Nevertheless, a statistically significant positive moderating impact of external finance dependence is documented which implies that the sectors which are more dependent on external finance gain disproportionate benefit from financial liberalization.
\end{abstract}

(C) 2020 The authors, under a Creative Commons Attribution-

NonCommercial 4.0

Corresponding author's email address: shafiquol@ hotmail.com

Recommended citation: Baloch, S., Fatima, K., Ahmed, J. and Noor, A. (2020). Response of Manufacturing Sector to Financial Liberalization in Pakistan. Journal of Accounting and Finance in Emerging Economies, 6(2), 583-592

\section{Introduction}

Financial liberalization is worldwide experience and is believed to be a stimulus to economic growth. Financial liberalization is described as a process through which market decides who obtains and allows credit and at what price (Williamson \& Mahar, 1998). The concept of Liberalization is opposite to that of financial repression where control lies with government to take major financial decisions. Williamson \& Mahar (1998) describe a number of major characteristics of liberalization as the removal of credit controls, deregulation of interest rates, removing obstacles to enter into financial services sector, banks independence in running their operations, ownership of banks by private sector and free movement of capital in international markets. Financial liberalization has rapidly transformed the financial system throughout the world. It has been a matter of discussion among policy makers in terms of financial restraints, management of risk, fundamental hazards and the instability of financial sector (Ahmed \& Islam, 2010).

The process of liberalization allows globalization of financial markets through liberalized shifts of capital facilitating 
the efficient allocation and use of resources. Therefore in past few years many developing countries including Pakistan have realized the importance of financial liberalization and adopted it as a tool for the development of industrialization; leading to the development of overall economy (Wizarat \& Adnan Hye, 2013). The focus before was on the development of infrastructure and agriculture sector but with the passage of time, the importance of financial sector development was realized by many developing countries including Pakistan. Studies such as (Koo \& Maeng, 2005); (Rajan \& Zingales, 1998); (Moshirian, 2007); (Raza, Akram, \& Farhan, 2011); (Henry, 2000) document that financial markets liberalization may lead to less credit restrictions, ease of access to finance, improved investment leading to economic growth in the country.

The importance of financial liberalization was first realized in late 1970s where Chile first liberalized through privatization of national banks, removal of control over interest rates and globalization of banks (Williamson \& Mahar, 1998). Argentina also followed the same practices and eliminated interest rates and credit controls. Lateron, till early 1980s, many East Asian, South Asian and South American countries opted the practices of financial sector reforms. However, in early 1980s Chile and Argentina faced severe macroeconomic crisis due to wrong sequencing of the reforms plan which directed the decision makers to focus on the unfavorable effects of the process of liberalization (Edwards, 1984).

Literature shows that there is not enough support of the positive consequences of financial liberalization on the developing economies as evidenced by Arestis \& de Paula (2008), the end result of the policies of financial liberalization in the developing countries is the financial crisis indicating that financial liberalization may not always has a favorable impact on the developing economies. In Asia financial liberalization is still a matter of controversy particularly after the financial crisis of 1997. IMF policies are considers as the major reason for this crisis by the Structuralists (Wizarat \& Adnan Hye, 2013). These policies included changes in labor laws, association between commerce and government and emergency loans. Despite this, continuous improvement in legislations and reforms by the states of many emerging countries have been made in the way of financial liberalization; but the response of industrial sector to this openness of financial markets is still divisive and vague.

Financial liberalization has been considered as an engine for economic growth on the one hand and also a source of financial sector unrest on the other hand (Ghosh, 2006). This study attempts to investigate the impact of financial liberalization on industrial response of manufacturing sector measured as the new firm entry in subsectors of manufacturing sector.

Industrial sector contributes $20.88 \%$ in the GDP of Pakistan including 64.4\% from the manufacturing sector (Finance, 2016-17). Due to the continuous development and contribution of industrial sector, researchers have focused exploring the role of industrial sector in the growth of an economy. The paper will make contribution in literature about the impact which financial sector reforms have on the new entry of firms in the manufacturing industry of Pakistan. It will provide an understanding of the connection between financial liberalization and entry of new firms as previous studies on financial liberalization have explored the linkage of liberalization witheconomic growth, firm's investment decisions and capital structure but its effect on the entry of new firms still remains to be investigated particularly in context of Pakistan. This study covers the response of industrial sector of Pakistan to financial liberalization policies in terms of entry of new firms only, however other factor which reflect the response of industry to the financial sector reforms are out of the scope of this study.

Rest of the paper is organized as follows. The next section reviews literature. Section 3 lays out methodology, section 4 present results followed by conclusion.

\section{Literature Review}

Minimizing risk is the main aim of any business. During past few years many developing countries have taken crucial steps to reduce risk by financial sector liberalization. Financial liberalization is the process of allowing the market to fix on the price at which credit is acquired and provided and also to decide about who gets and provides it. In the period of financial liberalization entrance of new firms in the industry is allowed, banks are given authority to run 
their operations, government departs from the possession of financial institutions and leaves the management of foreign capital engagements (Williamson \& Mahar, 1998).

Before the period of liberalization, the discount Rate was higher; which urged business banks to prepare their own supports as opposed to get from the central bank (Chipeta \& Mkandawire, 1996). Financial liberalization policies stimulate commercial banks to borrow from central bank thus increasing the volume of investment in society and fostering financial development.According to Gerschenkron (1962) banks in the developing countries can successfully enhance economic growth in many ways such as tempt firms to pay debts, surmount market breakdown, channel household reserve funds to deliberately essential ventures and provide financial support to the expansion projects. The executions of these policies are viewed as effective in improving monetary framework intermediation and intensity (Kabango \& Paloni, 2011). Monetary development cannot always be experienced in the lower income and politically week nations. In general the countries where political conditions are stable and are in the process of continuous development provide a pace for the development of those industries which depend highly on external finance (Beck \& Levine, 2002). It indicates the need for lawful changes by the policy making authorities to be concentrated for the advancement of financial institutions in the developing nations. Maksimovic \& Demirgüç-Kunt (1998) also point out that the states with strong political system have their firm's greater access to the external finance; resulting in more rapid economic growth.(Laeven, 2003) shares similar study experience as for affluent financial liberalization, political determination and capacity to stop the particular treatment of all around associated firms is needed that have a tendency to be liberal.

Since 1980 many financial institutions have been established in the developing countries and this process is still in progress. In the end of $19^{\text {th }}$ century, numerous Asian and African nations adopted economic development policies in order to bring a liberal financial framework which additionally included financial sector reforms called as financial liberalization (Ahmed \& Islam, 2010). Financial liberalization considerably affects the effectiveness of investment (Galindo, Schiantarelli, \& Weiss, 2007). An expanded offer of industry would expand work openings, raise salaries, and eventually develop the ways of life for a nation. (Love, 2003) demonstrates that financing constraints are reduced due to the advancement of financial sector, as the greater restrictions on investment lead to less availability of the domestic finance. This availability of funds can be improved through the lessened restrictions on external funds which is the primary target of liberalization. Reviewing the literature shows that, in the period of financial liberalization, investment constraints on the firms are lessened. According to (Bhaduri, 2005) in financial liberalization financial constraints on firms are relaxed thus it affects investment choices. In imperfect market firms face hurdles in gaining access to both external and internal finance which not only affects their financial situation but also their investment decisions however; due to the irregularity of data of lenders and borrowers the cost of outside fund is higher than domestic one (Myers \& Majluf, 1984). Thus external financing for investment is improved by reducing the financial constraints on firms (Koo \& Maeng, 2005).

The impression financial liberalization has on the investment can be viewed as a guide through which economic growth is facilitated (Koo \& Shin, 2004). Gregorio \& Guidotti (1995)explain that the key of achieving economic growth through financial development is investment's efficiency and not its size indicating that there exists an association between growth of an economy and financial sector development. According to (Shaw \& Edward, 1973) a positive correlation exists between the financial sector development and economic growth. They are in a view that financial liberalization plays a key part in boosting investment and saving in the economy. In current years however, researchers focus has been shifted from seeing the association between development of financial sector and growth of an economy towards the ways through which economic growth can be realized by the expansion of the financial sector. According to (Greenwood \& Jovanovic, 1990) Growth of financial institutions leads to economic growth. These financial institutions help in taking wise decisions about proper allocation and use of capital. Dealing with a particular financial institution called as concentration banking facilitates the growth process by providing credit access to the new firms which consequently leads to the adaptation of modern technologies by these firms. It slows down the availability of credit in the economy thus facilitates the industries that rely greatly on external finance which in turn leads to the industrial sector growth(Cetorelli \& Gambera, 2001).

Despite this, the impression of liberalization on the investment is still uncertain (Levine \& Renelt, 1992). The purpose 
of financial sector reforms was to reduce financial constraints on the availability of funds.However, there is little evidence of greater availability of funds to the firm as an outcome of the process of liberalization. Studies also state that financial liberalization relaxes the financing restraints for medium sized firms while small and new firms face more financing constraints than the large ones even in the period of liberalization. (Hermes \& Lensink, 1996) find that the approach of small and new firms to outer finance is not improved by financial reforms. The process of liberalization provides firms with access to external finance thereby increasing economic growth in the country where small and established firms face more financing constrains than large ones however these small and established firms gain wider access to external funds than large ones in post liberalization period (Koo \& Shin, 2004). It is because on the one hand borrowing costs for small sized firms increase and on the other hand firms also gain greater access to finance (Harris, Schiantarelli, \& Siregar, 1994). (Kabango \& Paloni, 2011) report that the large and deep rooted firms are benefited from financial liberalization and the small and medium sized firms still confront financing restrictions in the period of financial development. According to the study of (Rajan \& Zingales, 1998) the industries where most of the new firms depend upon external finance, gain more credit access and as a result grow more with financial liberalization as compared to those which are older and dependent less on external finance. (Beck, Laeven, Levine, \& Demirgüç-Kunt, 2008) state that in the period of financial liberalization, small sized firms grow more as compared to the larger ones. Financial liberalization facilitates small firms to gain access to the external finance while large firms' access to credit reduces in the period of liberalization (Ghosh, 2006). These restrictions are also affected by the firms' strong associations with financial institutions such as in the case of conglomerate organizations; they face less financial restrictions and their spending is also not much affected by domestic finance (Cho, 1996).

The effects of monetary reforms are limited in the developing nations therefore financial liberalization alone is not adequate to increase savings, provide access to monetary administration and expand investment by the private sector (Chipeta \& Mkandawire, 1996). It is because even after liberalization effective asset activation and monetary intermediation is restrained. (Grabel, 1995) examines some unfavorable effects of financial liberalization such as extreme misallocation of assets and increased financial constraints due to progressive eliminating of sponsored credit programs. It can result in higher acquiring costs and subsequently, in the short term, possibly will also slow down the economic growth process (Bhaduri, 2005). (Kabango \& Paloni, 2011) find the result of liberalization (i.e., a particular strategy contribution, instead of budgetary improvement, which is an arrangement yield) questionable on both hypothetical and observational grounds. According to the study of (Gelos \& Werner, 2002)in Mexico, financial liberalization results into increase in number of potentially entitled for credit firms and does not much explain the benefit of cost of external finance over domestic finance; concluding that financial liberalization does not always result in the reduction of financial restrains. It is because even after liberalization, organizations may furnish credit generally to customers with long-standing connections in this manner sustaining section obstructions particularly for the organizations that rely more on external funds. This in turn leads to the industrial sector become more concentrated where few firms gain control over the industry, set prices and enjoy profits through oligopolistic competition.

\subsection{Financial Liberalization in Pakistan}

Pakistan's economy is agriculture based. Agriculture serves as a lifeline for the economy and accounts for $19.5 \%$ of the GDP of the country; On the other hand manufacturing industry in Pakistan is facing major constraints such as old technology, unskilled labor force, energy shortage and high trade tariffs affecting the productivity and efficiency of the industry However, according to the (Economic Survey of Pakistan, 2016-17) the economy has a greater potential for growth and to become world's $20^{\text {th }}$ largest economy by the year 2030. As stated by (Reinhart \& Tokatlidis, 2003) "Liberalization is like running in a race you may run and not win, but you can't win if you don't run". To financially liberalize the economy like many other developing countries, policy makers have introduced financial sector reforms in Pakistan such as interest rate liberalization, privatization and deregulations. Consequently, an increase in industrial sector growth is observed, i.e. contribution of manufacturing sector in GDP increased to 20.88\% in the year 2016-17.

Financial reforms including banking sector reforms first introduced in Pakistan in 1980s (Financial Sector Assesment, 2003). These reforms consisted of launching of different instruments such modarabas, term certificates and musharikah. In 1991 access to finance was eased by licensing of private banks (Di Patti \& Hardy, 2005). More conventional reforms were introduced in the year 1990-1991 where 10 private banks were allowed to start operations 
and the government introduced federal investment and treasury bills bonds in order to auction the public debt in open market (Khan \& Aftab, 1994). In 1992 a system of deposits ratio was launched which was a major deregulation of the money market. State bank of Pakistan raised the liquidity ratio in the same year in order to meet budgetary deficit and foreign investors were given access to stock exchange which resulted in increase in market capitalization (Khan \& Aftab, 1994). Policies of IMF regarding limits on debt-equity ratio and availability of finance to individual investors were also implemented in 1995 by the state bank (Wizarat \& Adnan Hye, 2013). By the end of 1997 it became easy for the foreign and domestic private banks to open new branches and govt banks were also forced to close their branches which were going out of business (Di Patti \& Hardy, 2005). In the period 2001-2003 structural reforms were initiated where United Bank and a minority stake in Habib Bank and National Bank were sold. In this regard in 2009; small and medium enterprises were benefited by introducing prudent regulations. Another step in this view was the National Financial Inclusion Strategy which included providing credit for microfinance, digital payments and small and medium enterprises risk sharing (Finance, 2016-17). To support this strategy government has also announced Prime Ministers Skill Development Program with the support of World Bank. National Doing Business Reform Strategy was also another step of the government towards financial sector reforms which included changes in legislations and technological improvements in order to facilitate small and medium enterprises (Doing Business Equal opportunity for all, 2017).

Financial sector reforms introduced in Pakistan, since 1980, have been a matter of discussion among the researchers and policy makers for years. Trade liberalization is considered as an important factor for the development of industrial sector in a country. The relationship between trade related reforms and the industrial sector of Pakistan has been studied by researchers like (Ahmed, Khan, Mahmood, \& Afzal, 2017) who found that trade liberaliztaion can lead to enhanced industrial productivity and improved product quality. However, (Nasir, 2014) examining the effect of trade liberaliztaion on entry and exit of firms in the industry found no significant relationship. Financial liberalization policies and their impact on Pakistan's banking industry has also been a center of attention among researcher as banks are considered to be the key contributors in the development of an economy. The prupose of financial sector reforms was to enhance banking sector efficincy and stimulate growth in the country. This is investigated by Iimi (2004) who found that the private and foreign banks have achieved eefficieny in their operations as a result of liberalized reforms nevertheless public banks remained inefficient colcluding that libarelziation may not always result in faster growth of banks. (Rizvi \& Khan, 2001) also colnclude with similar results. They found stagnat inefficency in overall banking industry over the years 1993-1998 which is the period after liberalization. Findings of Di Patti \& Hardy (2005) are also equivalent to those mentioned above. According to them state owened banks remain inefficect in the period after liberalization and only private and some of the foreign banks get benefited from it. Wizarat \& Adnan Hye (2013) document a positive rtelationship between liberalization and economic growth in Pakistan in the short run. They suggest the State bank of Pakistan to persue those finacial liberaliztion policies which bring stability in the country in the long run.

In the light of above studies a gap has been seen in the literature regarding the impact of financial liberlization on the performance of manufacturing industry in Pakistan.

This paper contributes to literature by examining the response of manufacturing industries to the financial liberalization in Pakistan in terms firm entry in the industry. This investigation is based on the idea that if financial liberalization improves credit allocation and credit becomes easily available to firms, it will encourage new firms to enter the industry. Moreover, Rajan and Zingales (1998) argue that structure of the industry determines the extent to which industry responds to financial development. This implies that the firms which are more dependent on external finance may benefit more from financial development. To examine this phenomenon in Pakistan, we measure the external finance dependence of firms in manufacturing sector and estimate the moderating effect of external finance dependence on the relationship between new firm entry and financial liberalization.

\section{Methodology}

\subsection{Econometric Model}

This study is based on quantitative research design to investigate the association of financial liberalization with new firm entry in the manufacturing industry of Pakistan. From the review of literature, it evident that financial 
liberalization removes credit constraints and provides an opportunity to banks and firms to expand their business leading to new entry of firms in the industry.

The association between financial liberalization and new firm entry may also be affected by some other factors such as dependence of the firms on external finance (Kabango \& Paloni, 2011). The sectors of manufacturing industry which are more dependent on external finance will earn disproportionate benefits of financial liberalization than those firms which can generate funds from internal resources. The efficient allocation of credit will encourage the new firms entry and hence growth. To examine the moderating effect external finance dependence on the association of financial liberalization and new firm entry, we incorporate the interaction of external finance dependence and financial liberalization in the model. Some other variables are included in the model as control variables such as industrial growth, economic growth and import intensity.

The following model is specified to find out the association mentioned above:

$$
Y_{i t}=\beta_{1}+\beta_{2} F L_{i t}+\beta_{3} E F D_{i t}+\beta_{3}(F L * E F D)_{i t}+\beta_{4} I G_{i t}+\beta_{5} E G_{i t}+\beta_{6} I I_{i t}+u_{i t}
$$

Where Y represents the variable of concern that is new firm entry, $\beta_{1}$ isconstant, $\beta$ coefficients indicate the change in variable $\mathrm{Y}$ due to change in predictor variables, FL is financial liberalization, $\mathrm{u}$ is the error term and the interaction of financial liberalization and external finance dependence (FL*EFD) is used in order to find out the moderating effect of external finance dependence on the relationship of financial liberalization and new firm entry. IG is the industrial growth, EG is economic growth and II is the import intensity, idenotes cross sectional units in panel data.Regression approach allows to represent the role of different determinants of new firm entry. The approach used for regression is ordinary least square with random effect in order to control for heterogeneity.

\subsection{Data and Variables of Study}

To estimate the model, eight sub sectors of manufacturing industries for which data was available for all variables were taken as sample. These include food and beverages, textile, paper and paper products, chemical and chemical products, other non-metallic mineral products, electric machinery and apparatus and basic metals. ${ }^{1}$ The sample period is 10 years from 2009-2018 due to the availability of data.

\subsection{Measurement of Financial Liberalization}

Financial liberalization is the measure of how easily borrowers and savers can be united and the certainty they have in each other (Rajan \& Zingales, 1998). It is calculated by the credit to GDP ratio of manufacturing sector (Kabango \& Paloni, 2011), (Rajan \& Zingales, 1998). This ratio measures the effect financial liberalization has on new entry of firms throughout the economy (Beck, Laeven, Levine, \& Demirgüç-Kunt, 2008). The private sector credit to total domestic credit ratio and ratio of liquid liabilities to GDP are also used as measures of financial liberalization (Kabango \& Paloni, 2011), (Love, 2003). These data are obtained from the website of State Bank of Pakistan.

\subsection{Measurement of External Finance Dependence}

External finance dependence is the difference between cash flow from operations and investment. It is the investment level which cannot be financed from internal cash flow(Maksimovic \& Demirgüç-Kunt, 1998). It is calculated as capital expenditures minus cash flow from operations divided by capital expenditures (Rajan \& Zingales, 1998). Cash flow from operations is obtained by summing up the cash flow from operations plus increase in payables, decrease in receivables and decrease in inventories (Rajan \& Zingales, 1998). These data are obtained from the financial reports of individual firms.

\subsection{Measurement of New Firm's Entry}

Data on new firm entry is not available therefore a proxy is used to compute net entry of firms in industry. The number of firms entering and leaving the industry which shows industry growth rate is used for this purpose (Kabango \& Paloni, 2011). These data are taken from Security Exchange Commission of Pakistan on request.

\subsection{Measurement of Control Variables}

Industrial growth describes the firms entering in the industry and continuing doing business due to the attractiveness

\footnotetext{
5. The sectors which include less than three firms, were also dropped. 
of the industry. It is calculated by the ratio of value added to GDP(Kabango \& Paloni, 2011), (Rajan \& Zingales, 1998). Economic growth is calculated by real GDP growth indicating that on one hand when economy is growing it may encourage new firm entry but on the other hand growth in economy will lead to lower interest rates, increased inflation and decrease in unemployment rate which in turn lead to lower entry of new firms (Highfield \& Smiley, 1987), (Moshirian, 2007). Import intensity is the measured as growth of manufactured imports divided by total imports. If imported inputs are widely available, it will encourage new firms to enter the industry however; it also shows competition faced by foreign products which leads to the domestic firms go out of business and leave the industry (Kabango \& Paloni, 2011). These data are obtained from the published reports of Census of Manufacturing Industries CMI Pakistan, Pakistan Economic Survey yearly reports; State Bank of Pakistan published reports, IMF country reports, publications of Pakistan Bureau of Statistics and the website of Securities and Exchange Commission of Pakistan.

The above- mentioned model in estimated using generalized methods of moment which is a preferred estimation technique over OLS as it takes into account the possible correlation between independent variable and residual by using appropriate instruments. Secondly, it does not require exact information about the distribution of error term (assumption of normally distributed error term is not required to meet). The variables in instrument set should be orthogonal to error term. We used lagged explanatory variables as instrument variables. The appropriateness of instrument variables is tested with J. statistics.

\section{Estimation Results}

The estimation results of the model specified in equation 1 are reported in Table 1 . The results show that external finance dependence has a negative impact on new firm entry. This may be due to the fact that financial repression tends to restrict access to bank credit which implies that the firms which are more dependent on external finance face constraints. Hence in absence of financial liberalization or development, the firms which are more dependent on external financial are not encouraged to enter the industry. The positive coefficient on financial liberalization shows a positive impact of financial liberalization on firm entry, however, $p$ value of 0.10 shows a weak statistical evidence of the impact. Nevertheless, it is interesting to note that positive and statistically significant coefficient on interaction term (external finance dependence* financial liberalization) shows that the firms which are more dependent on external finance can get more benefits from financial liberalization as compare to those firms which rely more on internal resources to finance their expenditures.

Table 1: Estimation Results of the model, $Y_{i t}=\beta_{1}+\beta_{2} F L_{i t}+\beta_{3} E F D_{i t}+\beta_{3}(F L * E F D)_{i t}+\beta_{4} I G_{i t}+$ $\beta_{5} E G_{i t}+\beta_{6} I I_{i t}+u_{i t}$

\begin{tabular}{|l|l|l|l|}
\hline Independent Variable & Coefficients & t- statistics & P-value \\
\hline External finance dependence & -2.93 & -2.57 & 0.0126 \\
\hline Financial liberalization & 2.59 & 1.65 & 0.1044 \\
\hline Import intensity & -0.12 & -2.19 & 0.0324 \\
\hline Economic growth & 3.20 & 3.36 & 0.0014 \\
\hline Industrial growth & -0.02 & -1.59 & 0.1158 \\
\hline External finance dependence*financial liberalization & 6.785106 & 3.47 & 0.0010 \\
\hline Probability (J. statistics) & 0.32 & \\
\hline
\end{tabular}

Notes: The model is estimated using Generalized Methods of Movements where dependent variable is New firm entry.

The negative effect of import intensity on new firm entry is statistically significant which implies that the local firms are facing competition from foreign firms and on failing to compete they are forced to leave the industry. The positive and statistically significant effect of economic growth on new firm entry shows that as the economy grows, it encourages firm entry. P-value of $\mathrm{j}$. statistics show that instruments used are appropriate and model is not over or under identified. 


\section{Conclusion}

Financial liberalization is considered as an important factor for economic growth in modern growth models. It is believed that it stimulates growth by efficient allocation of credit in the economy. The efficient and easy availability of credit encourages the existing firms to increase their scale and attracts new firms to enter the industry by creating investment opportunities which in turn leads to economic growth. However, for the case of developing economies, financial liberalization is also suspected as a source of financial crisis despite the fact that many developing countries are taking several measures to financially liberalize their economies. Pakistan is also amongst those developing countries who are undertaking financial sector reforms.

To investigate the impact of financial liberalization, this paper aims to estimate the response of manufacturing industry to financial liberalization in terms of new firm entry. In addition to this, it is argued that intensity of the effect of financial liberalization on industrial growth is determined by the structure of industry. The sectors of industry which are heavily dependent on external finance gain more from financial development while the sectors which rely more on internal resources of finance are less affected by financial development. This paper attempts to estimate the impact of financial liberalization on new firm entry by taking a sample of eight sub sectors of manufacturing industry over a period of 2009-2018. Moreover, to estimate the moderating effect of external finance dependence an interaction term of financial liberalization and external finance dependence is introduced in the model. The model is estimated using Generalized Methods of moments, dynamic panel model. We found a negative impact of external finance dependence on new firm entry, positive but insignificant effect of financial liberalization on firm entry. Nevertheless, statistically significant positive moderating effect of external finance dependence is observed which shows that the firms with more external finance dependence may benefit more from financial liberalization.Import intensity and industry growth have a negative impact on firm entry.

These results have important policy implications. The firms which are more dependent on external finance are those which need large capital investments. Hence, consistent and long-term policies of financial liberalization must be focused on these sectors. This will not only reduce the import bills of Pakistan rather it will increase the competitive position of domestic firms. Future studies may be conducted on measuring the effect of financial liberalization on concentration of firms in industry as the impact on new firm entry only is not a comprehensive measure of industrial response to financial liberalization.

\section{References}

Ahmed, A. D., \& Islam, S. M. (2010). Financial Liberalization in Developing Countries. Melbourne 3000, Australia: Springer-Verlag Berlin Heidelberg.

Ahmed, G. (2017, December). Trade Liberalization and Industrial Productivity: Evidence form Manufacturing Industries in pakistan . Pakistan development review, 56(4), 319-348.

Arestis, P., \& de Paula, L. F. (2008). Financial Liberalization and Economic Performance in Emerging Countries (1st ed.). (P. Arestis, \& L. F. de Paula, Eds.) NewYork: Palgrave Macmillan.

Beck, T., \& Levine, R. (2002). Industry growth and capital allocation: Does having a market- or bank-based system matter? Journal of Financial Economics, 64(2), 147-180.

Beck, T., Laeven, L., Levine, R., \& Demirgüç-Kunt, A. (2008, October). Finance, Firm Size, and Growth. Journal of Money, Credit and Banking, 40(7), 1379-1405.

Bhaduri, S. N. (2005). Investment, financial constraints and financial liberalization: Some stylized facts from a developing economy, India. Journal of Asian Economics, 16(4), 704-718.

Cetorelli, N., \& Gambera, M. (2001, April). Banking Market Structure, Financial Dependence and Growth: International Evidence from Industry Data. The Journal of Finance, 56(2), 617-648.

Chipeta, C., \& Mkandawire, M. L. (1996, February). Financial integration and development in sub-Saharn Africa: The formal and semi-formal financial sectors in Malawi.

Cho, Y. D. (1996). Financial factors and corporate investment: An empirical analysis of Korean manufacturing firms. Avebury. 
Di Patti, E. B., \& Hardy, D. C. (2005). Financial sector liberalization, bank privatization, and efficiency: Evidence from Pakistan. Journal of Banking \& Finance, 29(8-9), 2381-2406.

(2017). Doing Business Equal opportunity for all. Washington DC: International Bank for Reconstruction and Development / The World Bank. doi:10.1596/978-1-4648-0948-4

Edwards, S. (1984, December). The Order of Liberalization of the ExternalL Sector in Developing Countries. Essays in International Finance, 156.

Finance, G. o. (2016-17). Pakistan Economic Survey.

Galindo, A., Schiantarelli, F., \& Weiss, A. (2007). Does financial liberalization improve the allocation of investment? Micro-evidence from developing countries. Journal of Development Economics, 83(2), 562-587.

Gelos, R. G., \& Werner, A. M. (2002). Financial liberalization, credit constraints, and collateral: investment in the Mexican manufacturing sector. Journal of Development Economics, 67(1), 1-27.

Gerschenkron, A. (1962). Economic Backwardness in Historical Perspective: A Book of Essays.

Ghosh, S. (2006). Did financial liberalization ease financing constraints? Evidence from Indian firm-level data. Emerging Markets Review, 7(2), 176-190.

Grabel, 1. (1995). Speculation-led economic development: a post-Keynesian interpretation of financial liberalization programmes in the Third World. International Review of Applied Economics, 9(2), 127-149.

Greenwood, J., \& Jovanovic, B. (1990). Financial Development, Growth, and the Distribution of Income. Journal of Political Economy, 98, 1076-1108.

Gregorio, J. D., \& Guidotti, P. E. (1995). Financial Development and Economic Growth. World Development, 23(3), 433-448.

Harris, J. R., Schiantarelli, F., \& Siregar, M. G. (1994). The Effect of Financial Liberalization on the Capital Structure and Investment Decisions of Indonesian Manufacturing Establishments. The World Bank Economic Review, $8(1), 17-47$.

Henry, P. B. (2000). Do stock market liberalizations cause investment booms? Journal of Financial Economics, 58(12), 301-334.

Hermes, N., \& Lensink, R. (1996). Financial Reform And Information Problems In Capital Markets:An Empirical Analysis of the Chilean Experience, 1983-1992.

Highfield, R., \& Smiley, R. (1987). New Business Starts And Economic Activity An Empirical Investigation. International Journal of Industrial Organization, 5(1), 51-66.

Iimi, A. (2004). Banking sector reforms in Pakistan: economies of scale and scope, and cost complementarities. Journal of Asian Economics, 15, 507-528.

Kabango, G. P., \& Paloni, A. (2011). Financial Liberalization and the Industrial Response: Concentration and Entry in Malawi. World Development, 39(10), 1771-1783.

Khan, S. R., \& Aftab, S. (1994). Assessing the impact of Financial reforms on pakistan's economy. pakistan journal of applied economics, 10(1\&2), 99-116.

Koo, J., \& Maeng, K. (2005, February 20). The effect of financial liberalization on firms' investments in Korea. Journal of Asian Economics, 16(2), 281-297. Retrieved March 19, 2018

Koo, J., \& Shin, S. (2004). Financial Liberalization and Corporate Investments: Evidence from Korean Firm Data. Asian Economic Journal, 18(3), 277-292.

Laeven, L. (2003). Does Financial Liberalization Reduce Financing Constraints? Financial Management, $32(1), 5-34$.

Levine, R., \& Renelt, D. (1992, September). A Sensitivity Analysis of Cross-Country Growth Regressions. The American Economic Review, 82(4), 942-963.

Love, I. (2003, July 1). Financial Development and Financing Constraints International Evidence from the Structural Investment Model. The Review of Financial Studies, 16(3), 765-791.

Maksimovic, V., \& Demirgüç-Kunt, A. (1998, December). Law, Finance, and Firm Growth. The journal of finance, 32(4), 2107-2137.

Moshirian, F. (2007, October 7). Globalisation, growth and institutions. (P. G. Szego, Ed.) Journal of Banking \& Finance, 32(4), 472-479. 
Myers, S. C., \& Majluf, N. S. (1984). Corporate financing and investment decissions when firms have information that investors do not have. Journal of Financial Economics, 13(2), 187-221.

(2003). Pakistan Financial Sector Assessment. State Bank Of Pakistan, Research Department. State Bank Of Pakistan. Retrieved from State Bank of Pakistan web site: http://www.sbp.org.pk/publications/FSA-2003/

Rajan, R. G., \& Zingales, L. (1998, June). Financial Dependence and Growth. American Economic Review, 88(3), 559-586. Retrieved March 20, 2018

Raza, A., Akram, M., \& Farhan, M. (2011, May). A Comparison of Financial Performance in Investment Banking Sector in Pakistan. International Journal of Business and Social Science, 2(9).

Reinhart, C., \& Tokatlidis, I. (2003). Financial Liberalization: The African Experience. Journal of African Economies, 12(2), 53-88.

Rizvi, S. F., \& Khan, A. H. (2001). Post-liberalisation Efficiency and Productivity of the Banking Sector in Pakistan. The Pakistan Development Review, 40(4), 605-632.

Shaw, \& Edward, S. (1973). Financial deepening in economic development. Business and Economics Review.

Williamson, J., \& Mahar, M. (1998). A Survey of Financial Liberalization (Vol. 211). (M. B. Riccardi, Ed.) Princeston, New Jersey, United States of America: Essays in International Finance.

Wizarat, S., \& Adnan Hye, Q. M. (2013). Impact of Financial Liberalization on Economic Growth: A Case Study of Pakistan. Asian Economic and Financial Review, 3(2), 270-282. 